\title{
Öst är öst och väst är väst? En jämförande studie av partisystemens stabilitet i Europa 2008-2019
}

\author{
Andreas Bågenholm* \\ Göteborgs universitet
}

\begin{abstract}
East is East and West is West? Comparing Party System Stability in Europe 2008-2019

This article compares trends in party system stability in Central/ Eastern Europe (CEE) and Western Europe, to see if recent studies indicating that the two regions have become more similar hold when the results of outcomes of several post-financial-crisis elections are taken into consideration. Further, it enquires into the underlying causes of electoral volatility and whether they differ between the two regions. In all, 82 parliamentary elections in 25 EU countries 20082019 are analyzed as regards electoral volatility (Pedersen's Index) and support for new parties ('volatility type A'). The results show that, when the most likely confounding variables are controlled for, a significant difference between the two regions remains, but also that there is a converging trend on both indicators. Moreover, whereas electoral volatility in the West is driven by the level of corruption together with the effective number of parties, unemployment and economic growth as well as the number of effective parties are the main factors explaining the same phenomenon in CEE. There is also evidence that volatility in CEE, unlike in Western Europe, is also driven by a path-dependent logic, where previous volatility scores explain subsequent ones. That finding may have implications for the prospects of future party system stabilization.
\end{abstract}

Keywords: party systems, stability, electoral volatility, Central and Eastern Europe, Western Europe

Även om Rudyard Kiplings berömda citat i titeln på denna artikel refererade till de oförenliga skillnaderna mellan Asien och Europa, passar det även bra för att beskriva den ambivalens som rått ända sedan Berlinmurens fall vad gäller synen på det nyligen demokratiserade Centraleuropa i relation till Västeuropa. Det råder naturligtvis ingen tvekan om att den politiska och ekonomiska omvandlingsprocess som inleddes 1990 har gjort skillnaderna mellan de båda regionerna väsentligt mindre; enpartisystemen har ersatts med demokratiska system, planekonomin med marknadsekonomi

^Kontaktinformasjon: Andreas Bågenholm, epost: andreas.bagenholm@pol.gu.se 
och genom EU- och NATO-medlemskapen är en stor del av lagstiftningen och relationerna med omvärlden gemensam. Trots detta har det fram till helt nyligen varit vanligt att analysera utvecklingen i Väst respektive Öst separat, inte minst vad gäller partisystemens utveckling. Det har förvisso funnits olika framtidsprognoser kring de central- och östeuropeiska partisystemens möjligheter att stabilisera sig, men det har fram till helt nyligen rått ett stort mått av samförstånd kring det faktiska läget: Den partipolitiska turbulensen i $"$ Öst $\rangle^{1}$ visar inga tecken på avmattning och skiljer sig därmed markant från utvecklingen $i$ "Väst», som under lång tid kännetecknats av stabilitet och kontinuitet (se till exempel Lewis, 2006; Mair, 1997; Bågenholm \& Johansson Heinö, 2013; Haughton \& Deegan-Krause, 2015). Få studier har dock systematiskt jämfört Öst och Väst och det är denna lucka som jag vill fylla. Syftet med studien är att undersöka i vilken utsträckning det fortfarande är rimligt att betrakta partisystemsutvecklingen i Central- och Östeuropa som distinkt annorlunda än den i Väst genom att jämföra väljarrörligheten i 25 länder i Europa mellan 2008 och 2019. Under denna period har flera studier pekat på ökad väljarrörlighet och en minskande stabilitet i Väst, vilket i så fall indikerar att "de två» faktiskt kan komma att mötas (se till exempel Chiaramonte \& Emanuele, 2015; Emanuele et al., 2018). Men det sker i så fall inte på det sätt som de flesta tidigare antagit, nämligen att Öst skulle stabiliseras, utan genom att Väst destabiliseras. Frågan är dock i vilken utsträckning detta är en korrekt beskrivning och alltså om det finns fog för påståendet att regionerna inte längre skiljer sig åt.

I nästa avsnitt kommer jag att kort presentera den tidigare forskningen på området och därefter diskuterar jag denna studies upplägg. Sedan följer en redovisning av de empiriska resultaten och avslutningsvis diskuterar jag hur studiens frågeställning bäst besvaras. Resultaten visar att det fortfarande är betydande skillnader mellan Öst och Väst vad gäller partisystemsstabilitet, men också att det finns en viss konvergerande trend - ökad instabilitet iVäst och minskande i Öst. Resultaten pekar också på att olika faktorer ligger bakom väljarrörligheten i Väst jämfört med den i Öst.

\section{Tidigare forskning}

Den här studien syftar till att undersöka i) i vilken utsträckning det fortfarande finns systematiska skillnader mellan Öst och Väst vad gäller partisystemsstabilitet, ii) hur trenderna ser ut i ett lite längre (och nyare) perspektiv - 2008 till 2019 - och iii) om det är olika förklaringar som driver väljarrörligheten i Öst och Väst och vad de i så fall säger om förutsättningarna för en framtida konvergens.

Avsaknaden av stabilitet har varit ett flitigt återkommande tema inom forskningen kring de postkommunistiska partisystemen. Oavsett hur stabilitet definieras och mäts och oavsett vilka jämförelser som gjorts har de postkommunistiska staternas partisystem framstått som synnerligen instabila (Engler, 2016; Epperly, 2011;

${ }^{1}$ Jag använder begreppen Öst och Väst som synonymer till Central- och Östeuropa resp.Västeuropa. 
Powell \& Tucker, 2014; Rose \& Munro, 2009; Mainwaring \& Zoco, 2007; Bielasiak, 2002; Bågenholm \& Johansson Heinö, 2013). Detta har stått i stark kontrast till partisystemsutvecklingen i Västeuropa, som under decennier kännetecknades av stabilitet och förutsägbarhet (se till exempel Lipset \& Rokkan, 1967, och Bartolini \& Mair, 1990). På grund av de stora skillnaderna mellan Öst och Väst har tidigare forskning studerat regionerna för sig och det finns fortfarande ytterst få jämförande studier på området (se dock Lane \& Ersson, 2007, och Emanuele et al., 2018).

Den fråga som sysselsatt de som huvudsakligen forskat om Central- och Östeuropa har kretsat kring orsakerna till varför partisystemen fortfarande inte stabiliserats och kopplat till den diskussionen, hur framtidsutsikterna för stabilisering ser ut. På ena sidan finns de som hävdat att de ekonomiska svårigheterna i samband med omvandlingen från plan- till marknadsekonomi är orsaken till instabiliteten och att med ekonomisk återhämtning så följer också partipolitisk stabilitet (Lane \& Ersson, 2007; McAllister \& White, 2007; Tavits, 2005). Flera studier har visat att ekonomisk tillväxt, låg inflation (Tavits, 2005) och socioekonomisk utveckling (Human Development Index) (Lane \& Ersson, 2007) har en signifikant påverkan på partisystemsstabilitet. Tavits menar också att trots att väljarrörligheten (volatiliteten) generellt sett ökar direkt efter en regimförändring, så påbörjas mycket snart en stabiliseringsprocess (Tavits, 2005: 296; se även Lupu \& Stokes, 2010). De fall som Tavits studerade uppnådde någon form av stabilitet efter ungefär elva år efter införandet av demokrati, men effekten av ekonomisk återhämtning avtog samtidigt. Det underliggande antagandet är därmed att tid i sig, allt annat lika, har en stabiliserande effekt. I varje nytt val förväntas väljarna bli mer och mer bekanta med och känna en allt större närhet till de partier som initialt var framgångsrika och dessa partier får i och med det mer medial uppmärksamhet på bekostnad av utmanarpartier. Det innebär i sin tur att avståndet mellan de etablerade och de icke-etablerade partierna ökar och detta gynnar de etablerade partierna och gör det svårare för nya partier att bli framgångsrika i senare val (McAllister \& White, 2007).

Även om partipolitisk stabilisering har varit det förväntade slutmålet i den forskning som behandlat utvecklingen i Västeuropa, så är inte alla lika säkra på att detta också kommer att ske i Central- och Östeuropa. Mainwaring och Zoco (2007: 171) menar till exempel att "the critical determinant of the stabilization of electoral competition is when democracy was born, not how old it is». Deras huvudslutsats är att volatilitetsnivåerna är avsevärt högre i länder som demokratiserats på senare tid, oberoende av hur länge man har haft demokrati. Lipsets och Rokkans (1967) infrysningshypotes, vilken åtminstone fram till helt nyligen gällde för större delen av Västeuropa, kan alltså inte automatiskt överföras till den central- och östeuropeiska kontexten. Redan 1997 förutsåg Peter Mair att de postkommunistiska staterna kunde förvänta sig ihållande partisystemsinstabilitet. Mair, och senare också andra, lyfte fram tre faktorer som han menade har en underminerande effekt.

För det första innebär kombinationen av svagt utvecklade partiorganisationer och svag partiidentifikation att volatiliteten fortsatt kommer att vara hög. En viktig 
skillnad mellan demokratiseringen i Central- och Östeuropa och tidigare liknande processer är att de politiska partierna bildades under eller efter regimförändringen. I Västeuropa däremot bildades partierna innan och de blev successivt mer och mer framgångsrika i takt med att rösträtten utvidgades. Vid tiden för demokratins genombrott var partisystemen redan mer eller mindre etablerade och stabila. I de postkommunistiska länderna bildades partierna runt 1989 eller senare och de har allt sedan dess, för att låna en fras från Abby Innes, varit "instant catch-all parties", vilka försökt vinna stöd från "all of the people, all of the time» (2002: 90). Partierna bildades uppifrån och ned under en kort period och de var starkt beroende av ett litet antal personligheter. Det gjordes få försök att bygga upp en medlemsorganisation bortom de mest nödvändiga strukturerna för att kunna rekryterera kandidater (van Biezen, 2003), vilket resulterade i starkt elitistiska partier, fjärmade från väljarna.

För det andra kan framväxten av partier med svag väljarkoppling förstås som en logisk konsekvens av avsaknaden av starka politiska skiljelinjer i regionen (Innes, 2002). Elster et al. (1998) menar att de postkommunistiska länderna också saknar ett diversifierat civilsamhälle, vilket innebär att dessa partier inte har någon förankring i sociala skiljelinjer utan istället flyter ovanför samhället (för en kritik mot detta perspektiv se Evans, 2006). Kopecky (1995) hävdar att en majoritet av väljarkåren 1990 inte bara var osäker på vad de nya partierna stod för, den hade inte heller några klart urskiljbara intressen. McAllister och White (2007) fann å andra sidan att väljarna i de postkommunistiska staterna uppvisade liknande sociala skiljelinjer som i de etablerade demokratierna, men menade att partierna i den förra regionen har varit betydligt sämre på att representera dessa skiljelinjer.

En tredje viktig faktor för att förstå den oförminskade instabiliteten är så kallade "valensfrågors» betydelse, det vill säga "issues on which all parties declare the same objective but dispute each other's competence in achieving the desired policy» (Kitschelt et al., 1999: 137). 1990-talet dominerades huvudsakligen av två frågor, den makroekonomiska liberaliseringen och EU-medlemskap. Det fanns en bred enighet bland regionens politiska elit om såväl syftet med de marknadsekonomiska reformerna som målet att bli medlemmar i EU. På grund av detta kom partisystemet att erbjuda ett högst begränsat ansvarsutkrävande. I teorin fanns olika partier att välja bland, men i praktiken utan några alternativa politiska inriktningar (Innes, 2002: 86). Oavsett vem som regerade landet var alla tvungna att genomföra mer eller mindre samma politik. Politiken kom därmed inte att handla om vad som skulle göras, utan snarare om vem som kunde göra det bäst. I opposition kunde ett parti dra nytta av att kritisera regeringens tuffa politik, men när de själva kom till makten hade de inget annat val än att genomföra samma politik.

Det har alltså funnits flera olika hypoteser till varför de central- och östeuropeiska länderna har haft väsentligt svårare att stabiliseras, men få har spekulerat kring de mer långsiktiga konsekvenserna av detta, det vill säga om vi överhuvudtaget kommer att se en stabilisering som liknar den i Väst. Bågenholm och Johansson Heinö (2013) har dock hävdat att man kan förvänta sig fortsatt instabilitet under 
överskådlig tid, eftersom det finns en självförstärkande effekt i instabiliteten som gör utvecklingen mycket svår att vända. Emanuele et al. (2018) ger en delvis annan prognos, nämligen att det kommer att ske en konvergens över tid, men inte genom att Öst blir mer likt Väst, utan tvärtom (se även Lane \& Ersson, som förutspådde detta redan 2007). De visar att de västeuropeiska staterna har blivit mer instabila under perioden 2010-2016, medan en motsatt trend har kunnat påvisas i Öst, vilket innebär, om trendlinjerna dras ut, att regionerna kommer att mötas någonstans på mitten. Under denna period, till skillnad från föregående, är heller inte skillnaden mellan Öst och Väst signifikant under kontroll för ett antal faktorer. Deras slutsats är därmed att det inte längre är korrekt att tala om ett Öst och ett Väst i det här avseendet, utan att gränserna nu har suddats ut.

Jag menar dock att dessa slutsatser kan vara förhastade, eftersom de bygger på trender från en tämligen kort tidsperiod, vilken också präglats av två stora kriser, finanskrisen och flyktingkrisen, vilka båda slog hårt mot flera västeuropeiska länder och skapade ett stort missnöje bland stora grupper i samhället. Det är därmed inte orimligt att tro att den ökade instabiliteten är tillfällig och att det kan komma att ske en stabilisering så snart effekterna av de båda kriserna har mattats av.

I Central- och Östeuropa finns det däremot indikationer på att logiken bakom partisystemens instabilitet är annorlunda, inte minst på grund av att det är framgångar för nya partier som driver väljarrörligheten och $\mathrm{i}$ mindre utsträckning att väljare byter mellan de etablerade partierna. I Västeuropa har det varit tvärtom (Emanuele et al., 2018). I en kontext där partisystemet är instabilt finns det få incitament för väljare eller politiker att agera på ett sätt som leder till mer stabilitet, eftersom de potentiella vinsterna med att ställa upp med ett nytt parti är höga, då det finns en stor chans att väljarna också röstar på tidigare icke-prövade alternativ. Till skillnad från stabila partisystem är kostnaderna betydligt lägre för att våga ge sig in $\mathrm{i}$ ett sådant projekt (se Sikk, 2005: 399). Eftersom utbudet av nya partier i varje val är högt och risken för att en röst på ett sådant parti är bortslösad är liten, är incitamenten för väljarna att prova nya alternativ också höga. Dessa incitament förstärks i tider av ekonomisk nedgång och korruption, vilket utmärker tiden efter murens fall och vilka också resulterade i regeringsbyten efter i stort sett varje val. Det finns således både ett utbud och en efterfrågan för nya partier och jag menar att det är rimligt att tro att incitamenten för att en sådan ömsesidig situation ska fortgå är mycket starka, medan argumenten för varför instabiliteten i Väst, åtminstone sett till alla regionens länder, ska fortgå är betydligt svagare.

\section{Avgränsningar, begrepp, metod och data}

Till skillnad från de flesta andra studier på området begränsas denna till perioden från finanskrisens utbrott 2008 fram till hösten 2019. Anledningen är att perioden fram till omkring 2010 är väldokumenterad och i princip alla resultat pekar på en stor skillnad mellan Öst och Väst. Under de senaste tolv åren har dock de partipolitiska 
kartorna ritats om i flera av de länder som drabbades hårt av finanskrisen och flera studier har också hävdat att det är i efterdyningarna av den som ett konvergensmönster uppträder. Det finns därmed goda skäl att fokusera på just denna period, som också täcker ett antal år efter finanskrisens slut. Studien omfattar alla 82 parlamentsval mellan 2008 och 8 oktober 2019 i 25 EU-stater. Cypern, Malta och Kroatien har däremot utelämnats. Cypern har utelämnats på grund av sitt presidentiella system och Malta eftersom man har ett pluralitetssystem, vilket i kombination med landets ringa storlek gör att endast två partier finns representerade och att volatiliteten är näst intill obefintlig, medan Kroatien inte tagits med på grund av att landet demokratiserades först tio år senare än de flesta övriga länder. ${ }^{2} 14$ av de 25 länderna har under denna period haft tre val. Undantagen är Polen, Frankrike och Irland som hållit två, Österrike, Belgien, Bulgarien, Lettland, Portugal och Slovenien (fyra), Spanien (fem) samt Grekland som haft hela sex val under perioden.

Partisystemsstabilitet kan och har mätts på flera olika sätt, men väljarrörlighet (volatilitet) är nog den vanligaste indikatorn. Den visar, på aggregerad nivå, andelen väljare som byter partier mellan två val och summan av procentförändringarna för alla partier delat med två kallas Pedersens index (se Pedersen, 1979) och löper således från 0 till 100. 0 innebär att alla parter har exakt samma andel av rösterna som vid föregående val och 100 att inget av de partier som vann röster i det föregående valet lyckades göra det i det följande. Ju högre värde på indexet, desto högre grad av väljarrörlighet och därmed instabilitet. Det är emellertid viktigt att påpeka att indexet inte säger något om väljarströmningar på individnivå. Om till exempel alla Parti A:s väljare byter till Parti B och vice versa, skulle volatilitetsvärdet fortfarande vara noll (om partierna är lika stora), även om båda parter inte behöll en enda väljare och alla väljare bytte parti. Det är givetvis ett hypotetiskt scenario och det har visat sig att den aggregerade volatilitetsnivån korrelerar högt med individnivån (Bartolini \& Mair, 1990: 29).

Eftersom det är nästan omöjligt att samla information om varje parti som ställer upp, räknar jag bara med partier som får parlamentarisk representation individuellt, medan partier som inte kommer in i parlamentet klumpas ihop i en "övriga»-kategori som jämförs med varandra mellan valen. Förutom att vara en valid och ofta använd indikator för partisystemsstabilitet har väljarrörlighet också fördelen att den är lätt att jämföra över tid och mellan länder.

Därmed inte sagt att det inte finns vissa begränsningar när det gäller att fånga partisystemsstabilitet och förändring med hjälp av enbart volatilitet. Till exempel betyder låg volatilitet inte nödvändigtvis att inget har förändrats i partisystemet. Partierna kan ha ändrat sin ideologi och politik samtidigt som de behåller sin väljarbas, vilket till exempel flera före detta kommunistiska partier i Östeuropa gjorde när de antog mer nationalistiska program. Inte heller innebär hög volatilitet

\footnotetext{
${ }^{2}$ Det är i sammanhanget inte relevant att undersöka övriga postkommunistiska länder eftersom de bara under kortare tid, om ens alls, har haft fullt demokratiska val.
} 
nödvändigtvis ett instabilt partisystem, så länge som skiftningarna antingen är mycket regelbundna eller sker mellan partier som står varandra ideologiskt nära (så kallad blockvolatilitet).

Som andra forskare har noterat är det inte alltid en så enkel sak att mäta väljarrörlighet (se till exempel Powell \& Tucker, 2014). Så länge de relevanta partierna som konkurrerar är mer eller mindre desamma är volatilitetsberäkningen dock inte särskilt svår, vilket är fallet för de flesta val i Västeuropa. I Centraleuropa är det väsentligen mycket mer komplicerat, beroende på att nya partier dyker upp, att valallianser bildas och upplöses, att partier byter namn och att partier splittras. Det är helt enkelt mycket svårare att följa ett enskilt parti från ett val till ett annat i regionen. Dessa svårigheter innebär också att volatilitetsnivåerna för Central- och Östeuropa tenderar att skilja sig markant forskarna emellan, medan nivåerna för Västeuropa knappast skiljer sig alls. Det kräver viss detalikunskap om de specifika partierna och partiutvecklingen i regionen för att kunna göra en exakt bedömning av volatilitetsnivån, men även bland de forskare som får räknas som experter på regionen skiljer sig fortfarande nivåerna, framförallt beroende på hur man beräknar sammanslagningar och nya partier (för en omfattande jämförelse, se Casal Bértoa et al., 2017).

Den grundläggande frågan att ställa sig är om väljarna har samma alternativ att rösta på som i föregående val och i vilken utsträckning de i så fall gör så. ${ }^{3}$ Helt nya partier, det vill säga partier som inte är efterträdare till något tidigare parti, deltar i sitt första parlamentsval och som främst innehåller kandidater som inte tidigare varit med i andra partier, har per definition inte deltagit $i$ tidigare val och därför blir volatilitetsvärdet för sådana partier detsamma som valresultatet. ${ }^{4}$ Alan Sikk diskuterar för- och nackdelarna med olika sätt att beräkna volatilitet (2005: 392-4) och i linje med honom beräknar jag också volatiliteten hos valförbund och nya partier som bildas genom sammanslagningar av två eller flera etablerade partier i förhållande till dessa partiers tidigare resultat, eftersom deras väljare fortfarande har mer eller mindre samma alternativ att rösta på i nästa val. ${ }^{5}$ De studier som väljer att betrakta partisammanslagningar på samma sätt som nya partier kommer därmed att få väsentligt högre, och enligt min mening överdrivet höga, volatilitetsvärden (se till exempel Powell \& Tucker, 2014). Jag skiljer mig emellertid från Sikk när det gäller den typen av nya partier, som bildas av politiker som bryter sig loss från sina gamla partier och som jag här benämner utbrytarpartier (splinter parties på engelska). Jag behandlar dessa på samma sätt som helt nya partier och inte som Sikk, som

\footnotetext{
${ }^{3}$ Ungerska Socialistpartiet (MSZP) fick till exempel 42,1 procent i valet 2002 och 43,2 procent 2006. Volatilitetsvärdet är då 1,1 dividerat med 2.

${ }^{4}$ NDSV i Bulgarien fick 42,7 procent i valet 2001 och beräknas alltså 42,7 dividerat med 2.

${ }^{5}$ Res Publica och Pro Patria gick samman inför parlamentsvalet i Estland 2007 och fick 17,9 procent av rösterna. 2003 fick de 31,9 procent tillsammans, vilket innebär att deras volatilitetsvärde är 14, dividerat med 2.
} 


\section{4 | ANDREAS BÅGENHOLM}

behandlar dem på samma sätt som partisammanslagningar. ${ }^{6}$ Detta ger som visas i fotnot 5 upphov till markanta skillnader i volatilitetsberäkningen och jag menar att Sikk underskattar den förändring som orsakas av en partisplittring. Enligt min uppfattning utgör denna typ av partier en mer fundamental förändring av den partipolitiska scenen än när allianser och sammanslagningar inträffar.

\section{Framgång för nya partier och utbrytarpartier}

Den andra indikatorn på partisystemsstabilitet är i vilken utsträckning nya partier har blivit representerade i parlamentet. Flertalet studier på detta område mäter de sammanlagda volatilitetsnivåerna, det vill säga de gör ingen skillnad på om dessa drivs av förändringar i röststöd mellan de etablerade partierna eller om de beror på att nya partier vinner framgångar på de etablerade partiernas bekostnad. Men som Powell och Tucker (2014) påpekar, mäter Pedersens index faktiskt två olika saker. Sara Birch (2001) var en av de första som tog upp denna fråga, men utan att göra mycket mer än att påpeka att nya partiers framgångar står för en betydande del av volatilitetsförändringarna i Central- och Östeuropa. Hon fann dock en hög korrelation (.48) mellan de två måtten (2001: 10). I de länder som tillhörde Sovjetunionen (de baltiska staterna, Ukraina, Moldavien och Ryssland) står nya partier för en större del av volatiliteten jämfört med länderna i Centraleuropa.

Men det var Powell och Tucker (2014) som var först med att verkligen göra en klar skillnad mellan de två typerna av volatilitet (typ A, som står för "A new party» och typ B, som betecknar "Between parties») och även med att testa om det är olika faktorer som driver de två typerna. I sin studie undersöker de 21 postkommunsitska stater och intressant nog finner de inte bara olika volatilitetsutvecklingar i de två typerna (en minskande trend $\mathrm{i}$ total volatilitet $(\mathrm{A}+\mathrm{B})$ och volatilitet typ A, men en jämn eller något ökande i typ $\mathrm{B}$ ). De finner också att de förklarande faktorerna (ekonomisk röstning, politiskt system, skiljelinjer och förändringar i väljarkårens storlek) har de motsatta effekterna på respektive volatilitetstyp, även om det bör påpekas att mycket få korrelationer är signifikanta. Föga överraskande finner de att den största delen av volatiliteten beror på de många extremt framgångsrika nya partierna som inte bara har lyckats vinna platser i parlamentet i sitt första försök, utan i många fall också har kommit att ingå i regeringarna, och ibland till och med lyckats knipa posten som premiärminister. Precis som i många liknande studier inkluderar Powell och Tucker länder av varierande demokratisk grad och deras sätt att definiera nya partier gör att de överdriver effekterna av typ A-volatiliteten.

\footnotetext{
${ }^{6}$ TOP09 bildades som en utbrytning ur ODS inför det tjeckiska parlamentsvalet 2010. De som röstat på ODS 2006 kunde alltså fortfarande rösta på samma parti, men också på det nya utbrytarpartiet. Jag beräknar alltså ODS volatilitetsvärde utifrån partiets valresultat $2006(35,4)$ respektive 2010 (20,2), alltså 15,2 dividerat med 2 och TOP09 utifrån deras resultat 2010 (16,7 dividerat med 2). Tillsammans får dessa partier i min beräkning ett volatilitetsvärde på 31,9 medan Sikk, som slår samman resultaten för ODS och TOP09 2010 (36,9), bara ger dem ett värde av 1,5.
} 
Även om man kan argumentera för att den här indikatorns effekt redan fångas av den första indikatorn (väljarrörlighet) så anser jag, i linje med bland andra Powell och Tucker (2014) att det finns en kvalitativ skillnad mellan omfördelningen av röster mellan ett antal etablerade parter å ena sidan och en omfördelning från etablerade partier till nya partier å den andra. Nya partier är per definition mindre kända för väljarna och de har därmed ingen möjlighet att avgöra i vilken utsträckning de är regeringsdugliga eller pålitliga. I ett stabilt partisystem ställs väljarna inför samma uppsättning partier, vars ståndpunkter, agerande och kompentens är mer förutsägbara och väldokumenterade och man kan under sådana förhållanden förvänta sig att väljarna utvecklar en närhet till partierna, vilket begränsar möjligheterna för nya partier att slå sig fram. Ett konstant flöde av framgångsrika nya partier är sålunda en bra indikator på ett partisystems instabilitet, i kombination med deras andel av rösterna.

Som nämnts ovan inkluderas inte bara nya partier utan även utbrytarpartier. Eftersom det ibland är mer än 50 partier som deltar i ett val är det omöjligt att spåra dem alla och ta reda på om de är nya, utbrytarpartier eller etablerade parter. Därför räknas endast nya och utbrytarpartier som kommer in i parlamentet, det vill säga de som är mest framgångsrika. Det innebär att rösterna för sådana partier underskattas något $\mathrm{i}$ undersökningen, men det motiveras av det faktum att partier som vinner mindre än 3-4 procent av rösterna endast har en begränsad inverkan på partisystemet. För att ett parti ska betraktas som nytt eller som ett utbrytarparti måste det komma in i parlamentet på första försöket, till skillnad från till exempel Emanuele et al. (2018) som betraktar varje nytt parti som kommer in i parlamentet, oavsett om de suttit där tidigare eller gjort flera tidigare försök att komma in. Partier som kommer in i parlamentet i sitt andra försök ingår således inte i denna indikator eftersom de i detta avseende anses vara "gamla» partier, även om de är nya i parlamentet. De destabiliserande effekterna av dessa partier fångas istället upp av volatilitetsindikatorn. ${ }^{7}$

De två beroende variablerna i studien är alltså väljarrörlighet generellt (som mäts genom Pedersens index) och framgångar för nya partier (som mäts genom att deras sammanlagda resultat i ett val divideras med två). Valdata kommer från Nordsieck (2019), men beräkningarna är egenhändigt gjorda. ${ }^{8}$

Den två huvudsakliga oberoende variablerna är dels region, det vill säga en dikotom variabel som antingen är Öst eller Väst, dels föregående volatilitet, som är ett genomsnitt av volatilitetsnivåerna i de två föregående valen. Denna avser att fånga upp om det finns en självförstärkande effekt av instabilitet, eftersom normalläget borde vara att ett land som haft ett instabilt val därefter stabiliseras, såsom

\footnotetext{
${ }^{7}$ Sverigedemokraterna och Alternativ för Tyskland räknas därför inte som nya partier när de kom in i respektive länders parlament 2010 och 2017, eftersom de deltagit i flera parlamentsval dessförinnan. Däremot räknas de danska partierna Nye Borgelige och Alternativet, vilka kom in i Folketinget på första försöket 2019 respektive 2015.

${ }^{8}$ Alla beräkningar är gjorda av mig bortsett från ett fåtal val i Västeuropa, där Emanueles et al. dataset har använts. Deras beräkningar ligger i övrigt väldigt nära mina egna, vilket innebär att dessa fall inte påverkar resultatet.
} 
till exempel Danmark gjorde efter jordskredsvalet 1973. En hög korrelation mellan volatilitetsnivån från ett val till nästa kan därmed ses som en indikation på att instabilitet föder instabilitet.

Jag kontrollerar för ett antal faktorer i regressionsanalyserna (OLS). För det första inkluderar jag tre "missnöjesvariabler», nämligen arbetslöshetsnivån, årlig BNP-tillväxt och korruptionsnivå. Samtliga är laggade ett år och kommer från Världsbanken (2019) respektive Transparency International (2019). För det andra kontrollerar jag för antalet relevanta (eller effektiva) partier, både antalet effektiva parlamentariska partier (Effective number of parliamentary parties, ENPP). ${ }^{9} \mathrm{Upp}-$ gifterna är hämtade från Gallagher (2019). Till skillnad från "missnöjesvariablerna" är partivariablerna inte laggade, det vill säga jag använder det värde som ett val resulterade i för det året. Anledningen är att jag anser att detta ger en betydligt mer rättvisande bild än värdet för valet innan (vilket blir konsekvensen om man laggar variabeln), eftersom partilandskapet kan ha genomgått stora förändringar sedan föregående val. Dessa är vanligt förekommande kontrollvariabler, men de är inte helt oproblematiska eftersom de ligger nära den beroende variabeln och därmed riskerar att "äta upp" effekterna av övriga variabler. Med stort missnöje bland väljarna följer även väljarrörlighet, med till exempel framgångar för nya partier, vilket också fångas upp av antalet effektiva partier. Jag betraktar därmed resultaten där dessa variabler är inkluderade som ett extremt tufft test.

\section{Resultat}

Ett första svar på frågan om Öst och Väst skiljer sig åt vad gäller partisystemsstabilitet presenteras i figur 1 där de 25 ländernas genomsnittliga volatilitetsnivå redovisas. Det övergripande mönstret är att det finns en skillnad mellan regionerna, men att det samtidigt finns flera avvikande fall. Samtliga fyra »extremfall» är postkommunistiska och bara ett av de elva mest stabila länderna kommer från Centraleuropa. Estland är därmed en tydlig outlier på "östsidan", medan Frankrike, Irland och Italien är de minst stabila västländerna. De sydeuropeiska länderna som drabbades hårdast av finanskrisen ligger utspridda och det är svårt att se något annat geografiskt mönster än det mellan Öst och Väst.

Genomsnittssiffror kan dock dölja stor intern variation. Det är skillnad om ett land ligger på konstant höga nivåer eller om enstaka "jordbävningsval» driver upp annars relativt sett måttliga nivåer. I figur 2 redovisas väljarrörligheten i samtliga 82 val som hållits i de 25 staterna mellan 2008 och den 8 oktober 2019. Den övre, blå grafen visar de 50 val som hållits i de 15 västeuropeiska staterna och den nedre

\footnotetext{
${ }^{9}$ Jag kontrollerar också för antalet effektiva partier som deltar i valet (Effective number of electoral parties, ENEP), vilken till stor del mäter samma fenomen som ENPP (korrelationen är .90). Dessa kan därför inte inkluderas i samma modell och redovisas inte i tabellerna nedan. Jag kommenterar dock de fall där resultaten förändras.
} 


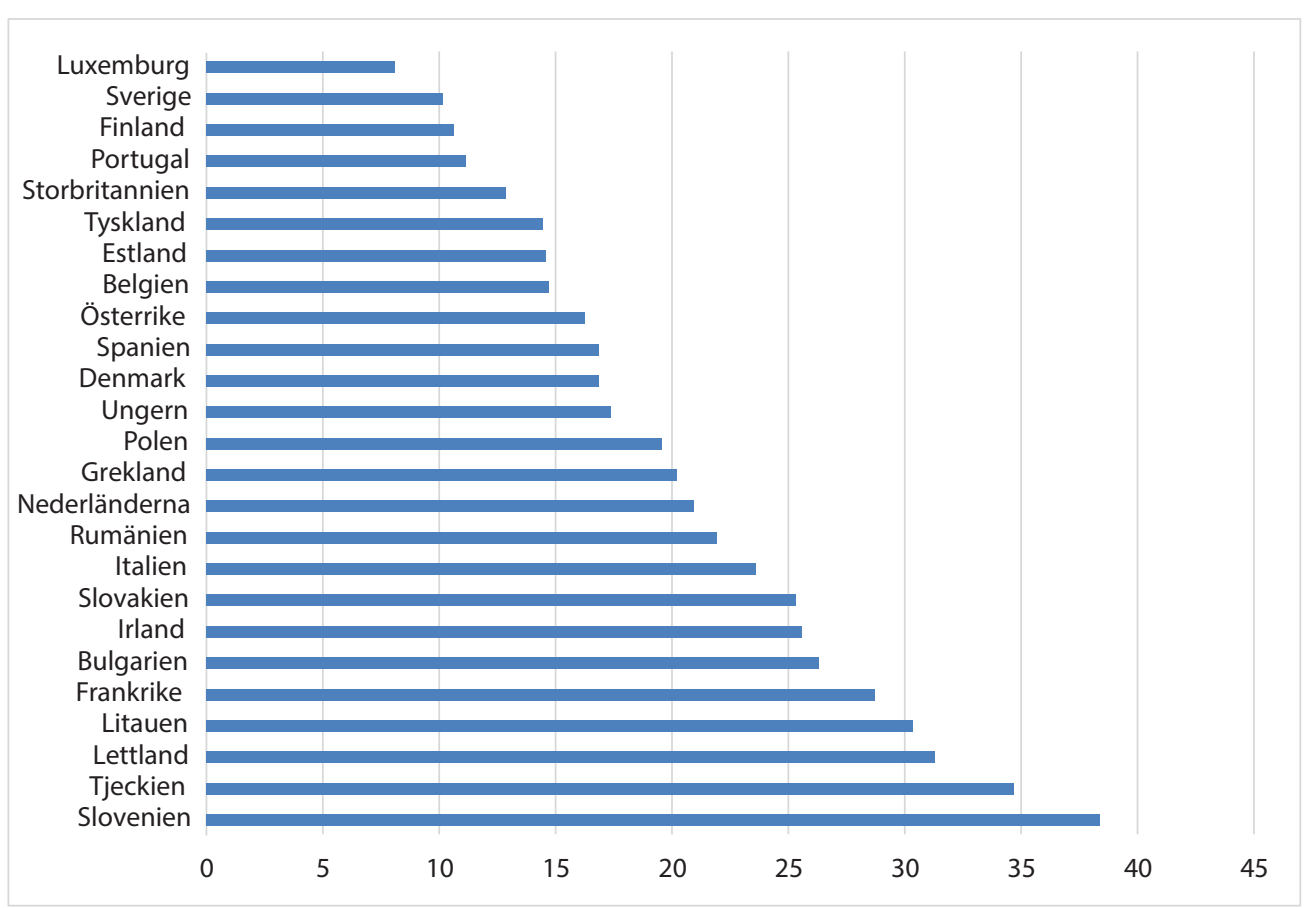

Figur 1. Genomsnittlig väljarrörlighet 2008-2019.

Kommentar: Beräkningen bygger på ländernas medelvärde av Pedersens index.

Källa: Egen beräkning utifrån valdata från www.parties-and-elections.eu

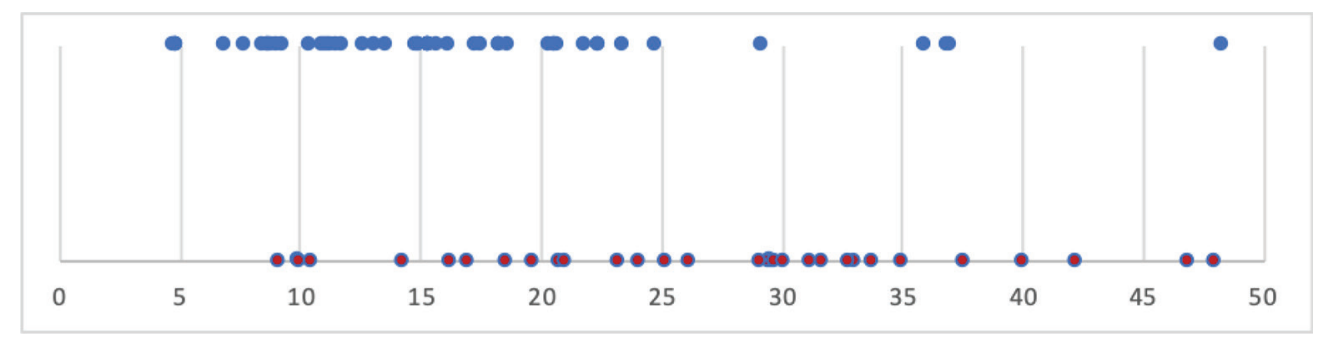

Figur 2. Jämförande väljarrörlighet 2008-2019.

Kommentar: Figuren visar Pedersens index för 82 val i 25 europeiska stater mellan 2008 och 2019. Den övre grafen (blå) visar de 50 valen i Västeuropa och den nedre (röd) visar de 32 valen i Central- och Östeuropa. Källa: Egen beräkning utifrån valdata från www.parties-and-elections.eu

(röda) de 32 som hållits i de tio staterna från Central- och Östeuropa. Sambandet mellan region och väljarrörlighet är statistiskt signifikant på 99\%-nivån och är skapligt starkt (.47). Men precis som i figur 1 så finns det en hel del överlappning mellan öst och väst. Allra högst nivå nåddes vid det första (av två) grekiska val 2012, följt av fem val i Öst. Av de 24 mest instabila valen hölls 19 i Central- och Östeuropa 
och endast fem i Väst. Omvänt är de elva minst instabila valen alla i Väst och bara fyra val i Öst ligger bland de 25 mest stabila. Jordskredsval inträffar förvisso även i Västeuropa då och då, men det är betydligt vanligare att detta sker i Central- och Östeuropa.

Den bivariata korrelationen gav oss en indikation på att det föreligger ett samband mellan region och väljarrörlighet. För att utesluta att detta beror på någon annan faktor som brukar förklara väljares missnöje, redovisas i tabell 1 en multivariat regression, med två ekonomiska kontrollvariabler, arbetslöshet och årlig BNPtillväxt (båda laggade till året innan valet), korruptionsnivån (också laggad) samt antalet effektiva parlamentariska partier (ENPP). Värdena på den sistnämna variabeln är från samma år som valet hölls, vilket motiverats i metodavsnittet ovan.

Som framgår av tabell 1 kvarstår den signifikanta effekten av region under kontroll för ovan nämna faktorer och skillnaden är drygt sex procentenheter i modell 1 och närmare åtta i modell 2 . Vi kan därmed vara ganska säkra på att skillnaderna mellan Öst och Väst fortfarande existerar, åtminstone sett till undersökningsperioden som helhet. Även korruptionsnivån, liksom antalet effektiva partier, påverkar väljarrörligheten i modell 1, men i modell 2, där ENPP är utesluten, är det enbart region som förblir signifikant och med något starkare effekt. Sex respektive åtta procentenheters skillnad är inte överdrivet dramatisk, men det innebär likväl en systematisk och substantiell skillnad mellan de bägge regionerna. De ekonomiska variablerna har ingen effekt i någon av modellerna.

Tabell 1. Förklarad väljarrörlighet i Europa 2008-2019.

\begin{tabular}{lcc}
\hline & $\begin{array}{c}\text { Modell 1 } \\
\text { Beta } \\
\text { (standardfel) }\end{array}$ & $\begin{array}{c}\text { Modell 2 } \\
\text { Beta } \\
\text { (standardfel) }\end{array}$ \\
\hline Korruption & $-2,275^{\star \star}$ & $-1,464$ \\
(laggad) & $(0,955)$ & $(0,922)$ \\
ENPP & $1,802^{\star \star}$ & \\
Arbetslöshet & $(0,746)$ & \\
(laggad) & $-0,075$ & $-0,071$ \\
Årlig tillväxt & $(0,237)$ & $(0,245)$ \\
(laggad) & $-0,120$ & $-0,135$ \\
Öst-Väst & $(0,234)$ & $(0,241)$ \\
& $-6,486^{\star \star}$ & $-7,685^{\star \star \star}$ \\
Konstant & $(2,775)$ & $(2,815)$ \\
& $31,798^{\star \star \star}$ & $35,215^{\star \star \star}$ \\
$\mathrm{R}^{2}$ & $(6,508)$ & $(6,549)$ \\
$\mathrm{N}$ & 0,31 & 0,26 \\
\hline
\end{tabular}

Kommentar: ${ }^{\star} \mathrm{p}<10 \%,{ }^{\star \star} \mathrm{p}<5 \%,{ }^{\star \star \star} \mathrm{p}<1 \%$. ENPP avser antalet effektiva partier i parlamentet. 
Det har sedan länge uppmärksammats inom partiforskningen att det är skillnad om väljarna byter mellan de etablerade partierna eller om skiftet sker från gamla till nya politiska partier. Som diskuterats ovan brukar den sistnämnda typen av volatilitet kallas typ A och den förstnämnda typ B. Volatilitet typ A anses vanligen indikera än mer instabilitet än typ B och det är just denna typ som varit utmärkande för den central- och östeuropeiska partisystemsutvecklingen jämfört med den i Väst.

I figur 3 redovisas de genomsnittliga värdena för volatilitet typ A, det vill säga det procentuella stödet för nya eller utbrytarpartier, dividerat med två. Föga förvånande hittar vi samma trend som i föregående jämförelse, nämligen att det finns en mycket klar dominans för framgångsrika nya partier i Central- och Östeuropa. Slovenien och Tjeckien ligger i en klass för sig. Här vinner nya partier i genomsnitt runt 23-24 procent av rösterna i varje val, vilket är en förbluffande hög nivå. Siffrorna i figuren kan förefalla låga, men man bör minnas att det verkliga stödet är dubbelt så högt och att det är medeltal för ett flertal val. I fyra länder lyckades inte något nytt parti att ta sig in i parlamentet under studiens tidsperiod och samtliga fall är från Väst. Slutsatsen här är att väljarrörligheten i högre utsträckning drivs av nya partiers framgångar i Öst jämfört med i Väst, det vill säga att det mönster vi sett sedan länge håller i sig.

Även vad gäller volatilitet typ A finns det en statistiskt signifikant korrelation med region på 99 \%-nivån och med en styrka på .42. I figur 4 nedan plottas stödet

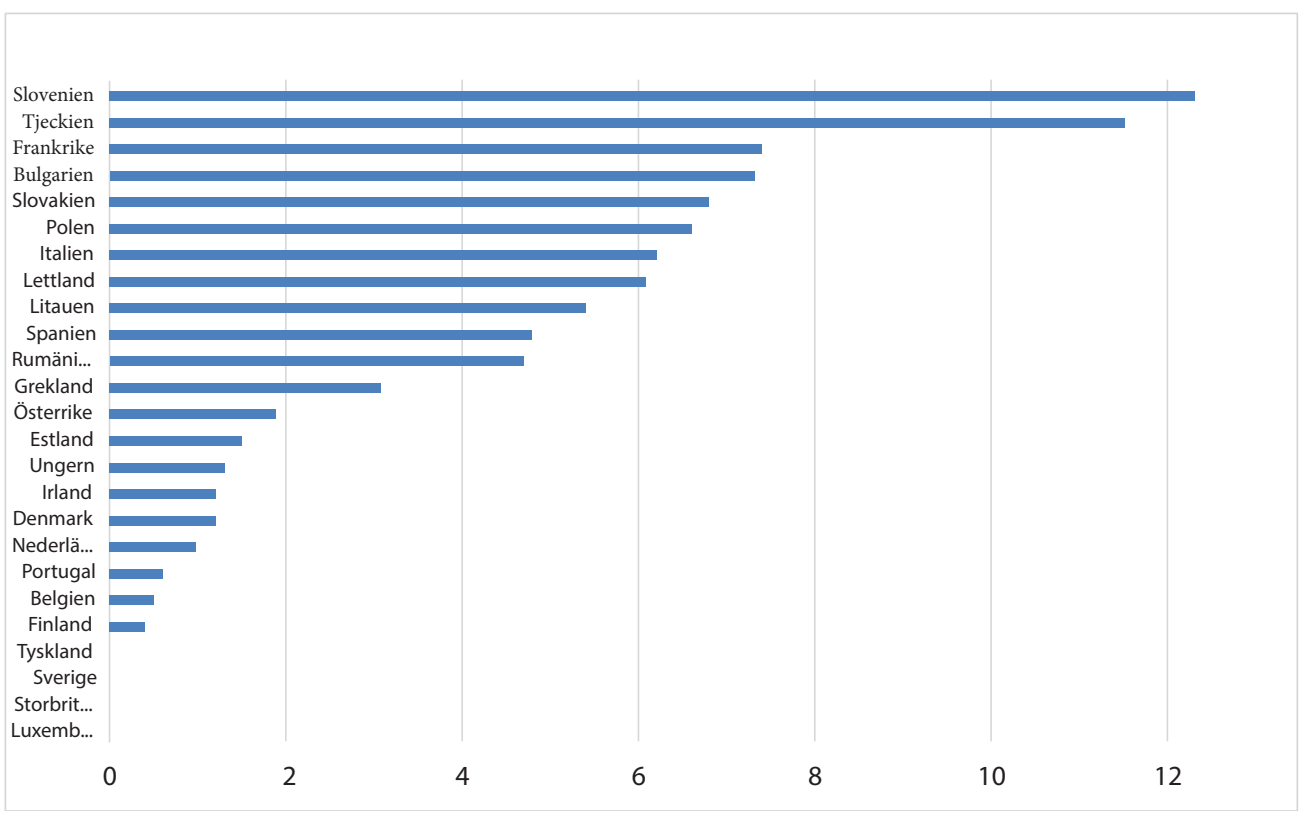

Figur 3. Stöd för nya partier i Europa 2008-2019.

Kommentar: Figuren visar ländernas genomsnittliga stöd för nya och utbrytarpartier.

Källa: Egen beräkning utifrån valdata från www.parties-and-elections.eu 


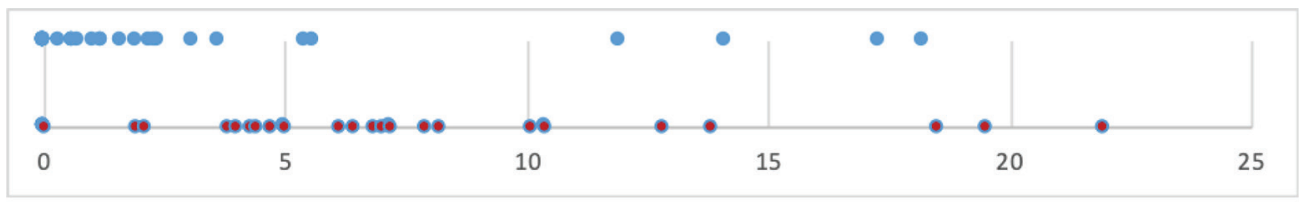

Figur 4. Stöd för nya partier i väst respektive öst 2008-2019.

Kommentar: Figuren visar volatilitet typ A för 82 val i 25 europeiska stater mellan 2008 och 2019. Den övre grafen (blå) visar de 50 valen i Västeuropa och den nedre (röd) visar de 22 valen i Central- och Östeuropa. Källa: Egen beräkning utifrån valdata från www.parties-and-elections.eu

för nya och utbrytarpartier i de 82 valen i Europa. Det som är särskiljande är inte så mycket extremnivåerna, vilka förekommer i bägge regioner, utan i intervallet 6-11 procent (alltså ett faktiskt stöd på 12 till 22 procent) där det helt saknas västländer. I endast fyra val (åtta procent av fallen) har nya partier vunnit mer än sju procent av rösterna i Väst, medan det förekommit vid 14 tillfällen i Öst, alltså i 44 procent av fallen. Vidare kan det konstateras att val där inga nya partier kommer in i parlamentet inträffar dubbelt så ofta i Väst (sammanlagt 22 val, det vill säga 44 procent) som i Öst, där det hänt sju gånger, vilket motsvarar 22 procent av valen.

Av tabell 2 framgår att även vad gäller graden av framgång för nya partier så har regiontillhörighet en kvarstående signifikant effekt under kontroll för samma variabler som i tabell 1, dock är effekten betydligt svagare jämfört med väljarrörlighet, endast mellan två och tre procentenheters skillnad. Resultaten liknar delvis dem i

Tabell 2. Förklarad volatilitet typ A i Europa 2008-2019.

\begin{tabular}{lcc}
\hline & $\begin{array}{c}\text { Modell 1 } \\
\text { Beta } \\
\text { (standardfel) }\end{array}$ & $\begin{array}{c}\frac{\text { Modell 2 }}{\text { Beta }} \\
\text { (standardfel) }\end{array}$ \\
\hline Korruption & $-1,210^{\star \star}$ & $-0,965^{\star \star}$ \\
(laggad) & $(0,498)$ & $(, 469)$ \\
ENPP & 0,547 & \\
Arbetslöshet & $(0,389)$ & \\
(laggad) & $-0,026$ & $-0,024$ \\
Årlig tillväxt & $(0,124)$ & $(0,125)$ \\
(laggad) & $-0,026$ & $-0,030$ \\
Öst-Väst & $(0,122)$ & $(0,123)$ \\
& $-2,467 \star$ & $-2,830^{\star}$ \\
Konstant & $(1,447)$ & $(1,433)$ \\
& $10,794 \star \star \star$ & $11,831^{\star \star \star}$ \\
$\mathrm{R}^{2}$ & $(3,394)$ & $(3,334)$ \\
$\mathrm{N}$ & 0,25 & 0,23 \\
\hline
\end{tabular}

Kommentar: ${ }^{\star} \mathrm{p}<10 \%,{ }^{\star \star} \mathrm{p}<5 \%,{ }^{\star \star \star} \mathrm{p}<1 \%$. ENPP avser antalet effektiva partier i parlamentet. 
föregående tabell. Korruption är signifikant även i modell 2 när effektiva partier tas ur ekvationen. Detta kan säkerligen förklaras med att många av de mest framgångsrika nya partierna just har haft korruptionsbekämpning som sin huvudfråga i såväl Öst som Väst. ENPP är inte signifikant, men om man istället inkluderar ENEP så blir denna signifikant, men ändrar inte resultaten i övrigt.

Vi kan alltså konstatera att det fortfarande förefaller finnas distinkta skillnader mellan Öst och Väst både vad gäller väljarrörlighet generellt och vad gäller framgångar för nya partier mer specifikt. Men hur ser trenderna ut i de två regionerna? Det har spekulerats i att en konvergens håller på att ske genom att länderna i Västeuropa blir allt mer instabila och därmed mer lika dem i Central- och Östeuropa. I figur 5 visas väljarrörligheten över tid i Central- och Östeuropa och i figur 6 samma sak för länderna i Västeuropa.

Trots att skillnaderna mellan Öst och Väst fortfarande är signifikanta, vilket tabell 1 och 2 visade, får konvergenshypotesen stöd: Det finns en svagt nedåtgående trend i Central- och Östeuropa och en lika svagt uppåtgående trend iVästeuropa vad gäller väljarrörlighet. Om denna trend håller i sig under ett antal decennier kommer vi så småningom att bevittna hur Västeuropa tar över som den mer instabila regionen i Europa. Huruvida denna trend kommer att hålla i sig och resultera i ett skifte är dock alldeles för tidigt att spekulera i. Dels är trendlinjerna känsliga för enstaka valresultat och dessutom beroende av vilken startpunkt som väljs, dels kvarstår betydande skillnader mellan regionerna. I Central- och Östeuropa sjunker volatiliteten från nära 30 till knappa 25 procent, medan trendkurvan stannar på knappt 20 procent i Västeuropa. Att enbart utifrån trendlinjerna dra slutsatser om framtiden är vanskligt, de kan lika gärna brytas som förstärkas. Om man drar ut dem till sin spets så kommer Väst så småningom att hamna på 100 och Öst på 0 , vilket är ett högst

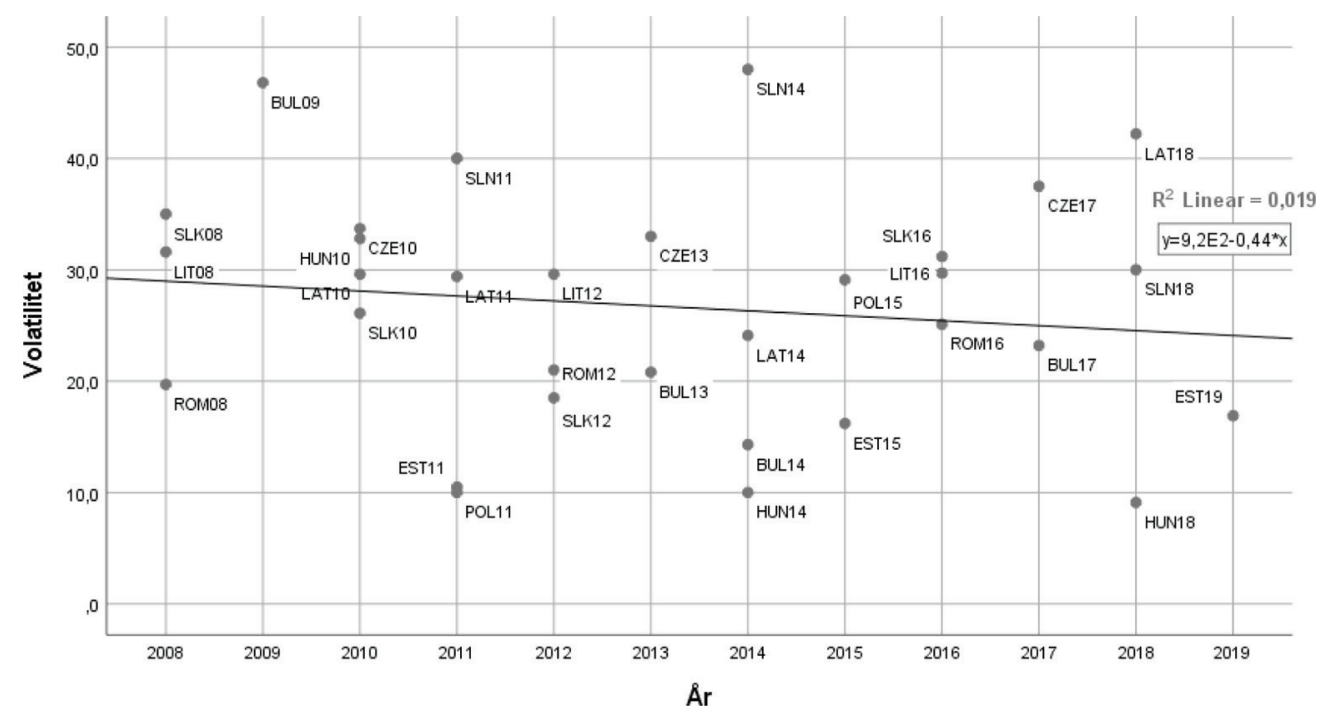

Figur 5. Trend i väljarrörlighet i Central- och Östeuropa 2008-2019. 


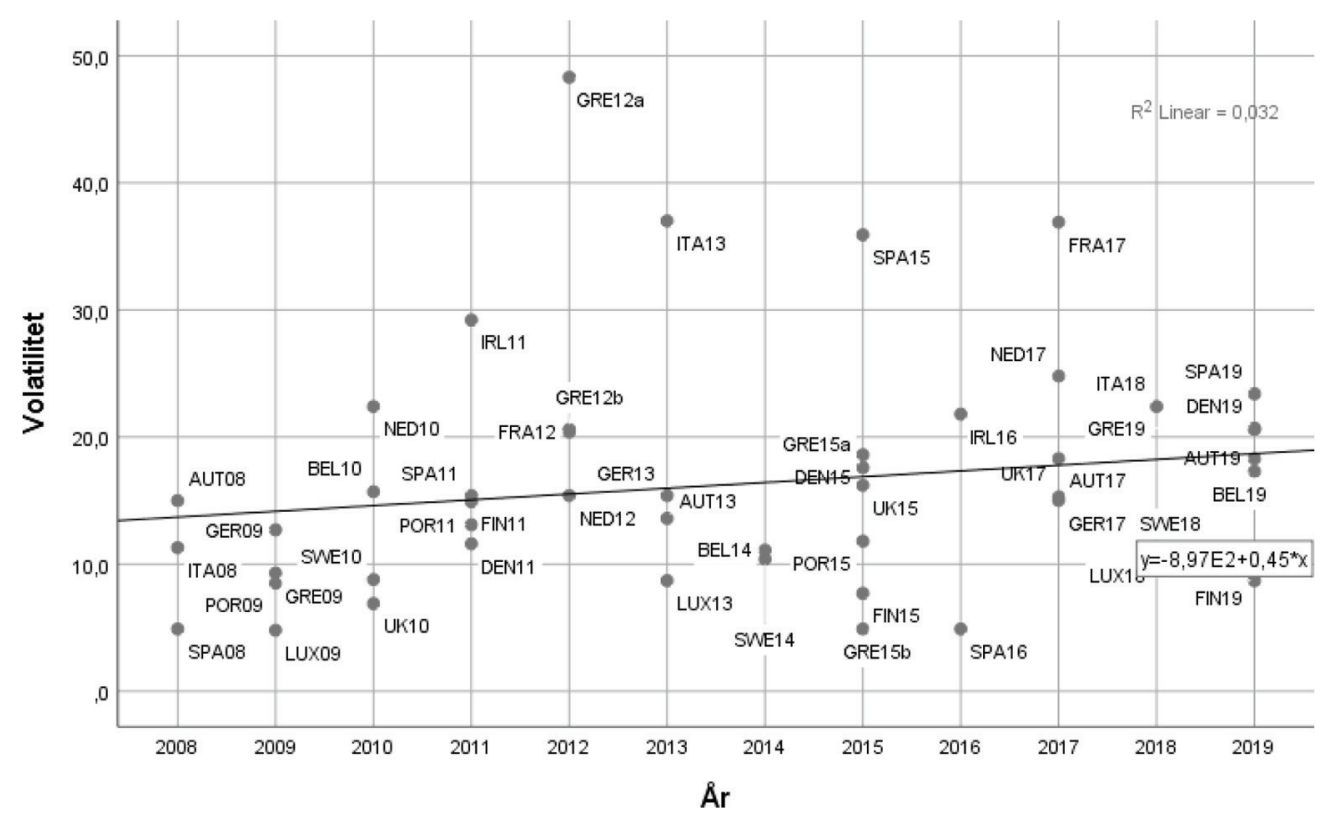

Figur 6. Trend i väljarrörlighet i Västeuropa 2008-2019.

osannolikt scenario. För att kunna tolka trenderna behöver vi veta vad som driver väljarrörligheten i respektive region, vilket jag återkommer till nedan.

Figur 7 och 8 visar trenderna i de båda regionerna vad gäller stöd för nya partier. Mönstret är detsamma som i de föregående figurerna. Trendlinjen är något brantare för Central- och Östeuropa, men något mindre så i Väst. Vad som också framgår är att variationen bland de postkommunistiska staterna förefaller att bli allt mindre över tid medan den inomregionala variationen iVäst ökar. Den senare observationen är kanske inte helt överraskande med tanke på de stora olikheter som finns mellan länderna i Väst vad gäller exempelvis korruption, ekonomiskt välstånd och inte minst gällande finanskrisens effekter. Härvidlag ligger länderna i Öst väsentligt närmare varandra. Det måste dock åter poängteras att sluttningen på linjen är än mer känslig för enstaka valresultat när det gäller stöd för nya och utbrytarpartier, eftersom variationerna mellan val i samma land är betydligt kraftigare. Det faktum att regionens två stabilaste länder haft val nyligen ger dessutom viss anledning att tro att kurvan kommer att plana ut när även de mer instabila länderna håller sina nästa val. Västeuropa känns mer oförutsägbart i och med att flera länder haft jordskredsval nyligen.

Vi har alltså kunnat konstatera att det finns en konvergerande trend mellan Öst och Väst både vad gäller väljarrörlighet generellt och framgång för nya partier, men att dessa trender är väldigt känsliga för enstaka valresultat, vilket gör det svårt att dra några säkra slutsatser kring om och i så fall när en konvergens kan inträffa. Med 


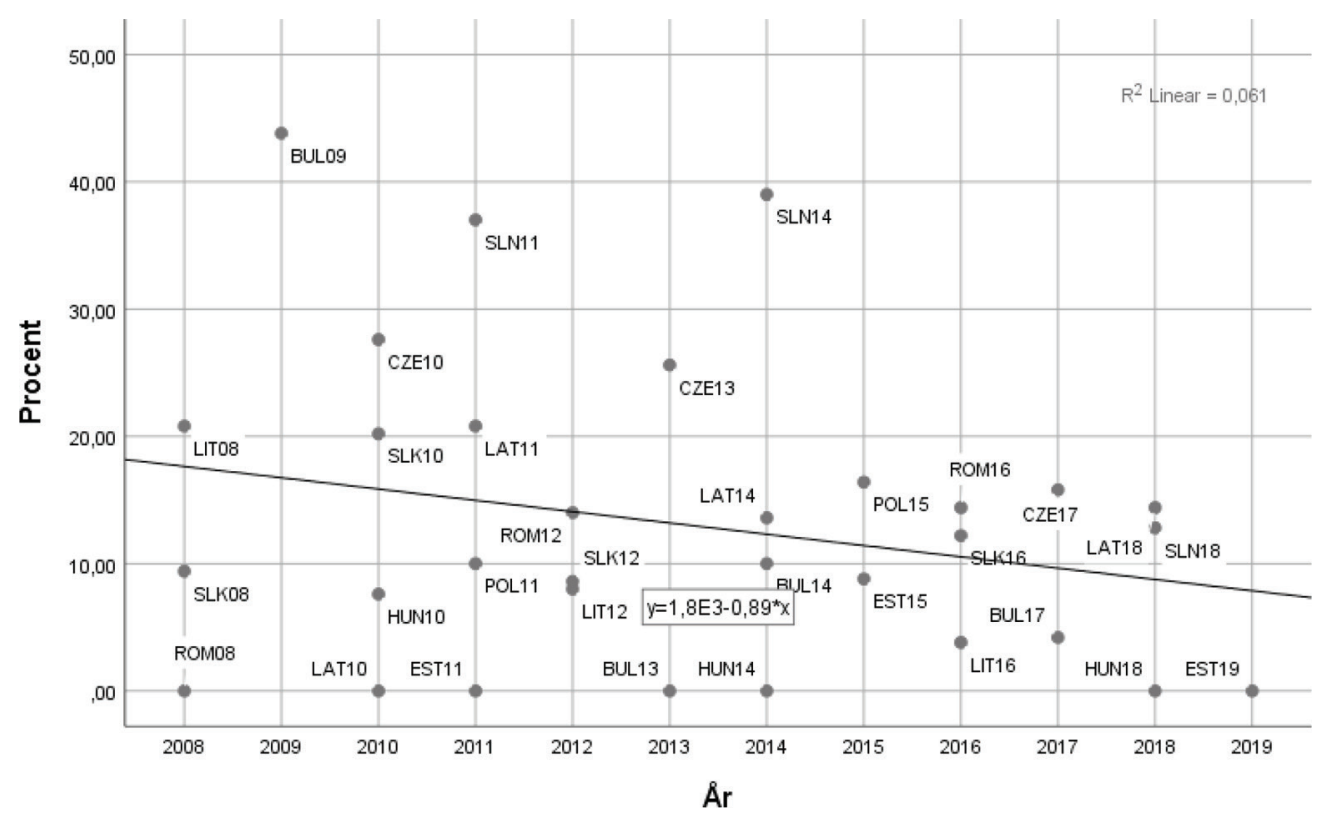

Figur 7. Trend för stöd av nya partier i Central- och Östeuropa 2008-2019.

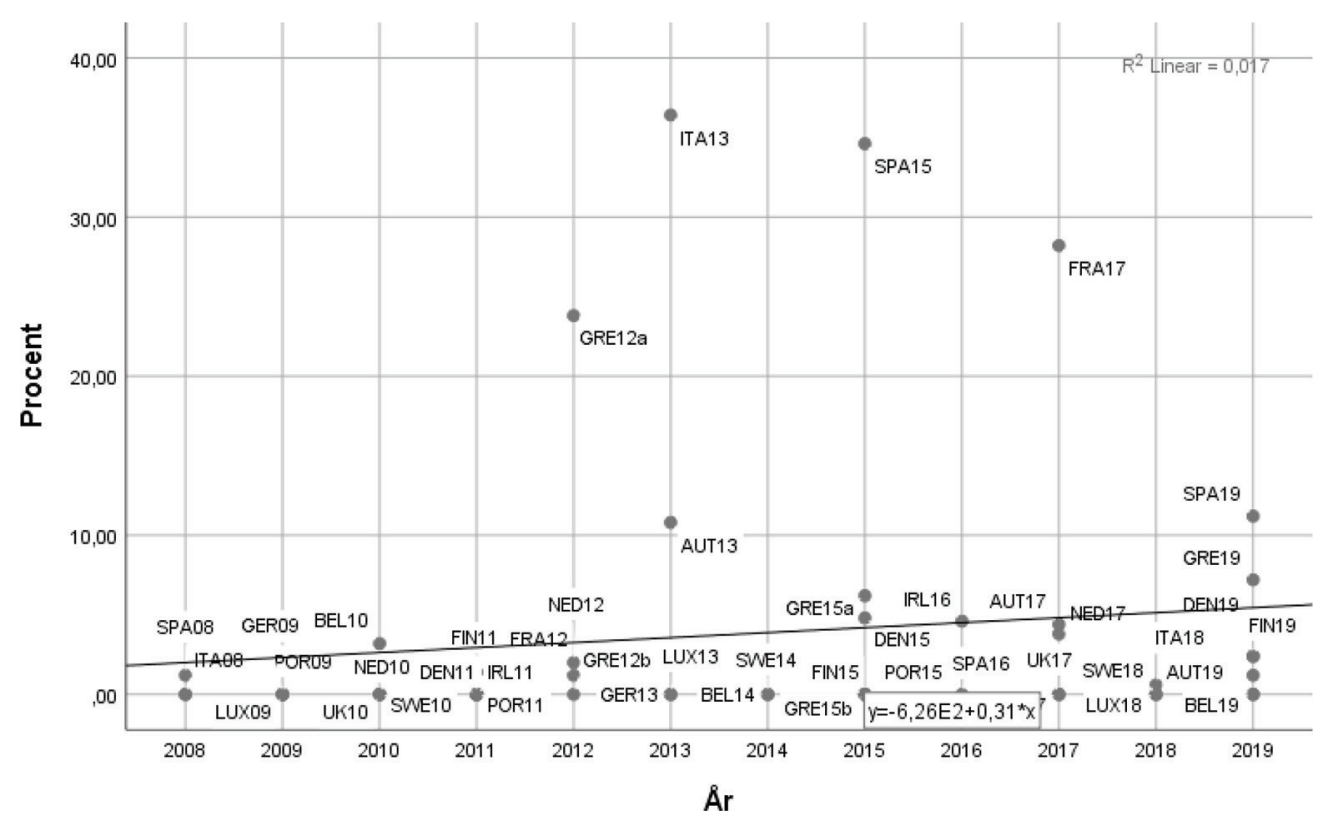

Figur 8. Trend för stöd av nya partier i Västeuropa 2008-2019. 


\section{4 | ANDREAS BÅGENHOLM}

tanke på att merparten av länderna i Väst fortfarande har mycket modesta nivåer av volatilitet, skulle en framtida konvergens troligen orsakas av ett fåtal länder i Väst snarare än en generell destabilisering över hela regionen.

Avslutningsvis ska vi undersöka om väljarrörligheten och graden av framgång för nya partier drivs av olika faktorer i Central- och Östeuropa jämfört med i Västeuropa. Jag kommer i detta avsnitt att introducera en ny variabel som tidigare visat sig förklara variationen i partisystemsstabilitet i Öst- och Centraleuropa, nämligen tidigare volatilitetsnivåer (Bågenholm \& Johansson Heinö, 2013), vars värde är den genomsnittliga volatiliteten i de två föregående valen. Implikationerna av den variabeln är att instabila partisystem lever sitt eget liv oberoende av nivåerna på diverse "missnöjesfaktorer». Man kan säga att instabilitet föder fortsatt instabilitet. Det är därför av stort intresse att både testa denna faktor på Väst och Öst sammantaget och sedan på respektive region separat.

I tabell 3 presenteras två modeller för att förklara väljarrörligheten bland samtliga 25 länder under den aktuella tidsperioden. I den första är endast "missnöjesvariablerna» samt tidigare volatilitet inkluderade och intressant nog är den sistnämnda tillsammans med korruption den som når upp till signifikansnivån, medan de båda ekonomiska variablerna är insignifikanta. I modell 2 inkluderas ENPP, vilket inte förändrar resultaten. Effekten av föregående volatilitet är hög. För varje procentenhets ökning ökar volatiliteten $\mathrm{i}$ det följande valet med 0,4 procentenheter, det vill säga nästan med hälften.

Tabell 3. Förklarad väljarrörlighet i Europa 2008-2019 revisited

\begin{tabular}{lcc}
\hline & $\begin{array}{c}\text { Modell 1 } \\
\text { Beta } \\
\text { (standardfel) }\end{array}$ & $\begin{array}{c}\frac{\text { Modell 2 }}{\text { Beta }} \\
\text { (standardfel) }\end{array}$ \\
\hline Korruption & $-1,789^{\star \star}$ & $-2,508^{\star \star \star}$ \\
(laggad) & $(0,802)$ & $(0,879)$ \\
ENPP & & $1,452^{\star \star}$ \\
Arbetslöshet & & $(0,780)$ \\
(laggad) & $-0,298$ & $-0,273$ \\
Årlig tillväxt & $(0,225)$ & $(0,222)$ \\
(laggad) & $-0,234$ & $-0,195$ \\
Föregående volatilitet & $(0,242)$ & $(0,239)$ \\
(genomsnitt två val) & $0,402^{\star \star \star}$ & $0,318^{\star \star}$ \\
Konstant & $(0,124)$ & $(0,130)$ \\
& $27,236^{\star \star \star}$ & $26,787 \star \star \star$ \\
$\mathrm{R}^{2}$ & $(7,549)$ & $(7,435)$ \\
$\mathrm{N}$ & 0,28 & 0,32 \\
\hline
\end{tabular}

Kommentar: ${ }^{\star} \mathrm{p}<10 \%,{ }^{\star \star} \mathrm{p}<5 \%,{ }^{\star \star \star} \mathrm{p}<1 \%$. ENPP avser antalet effektiva partier i parlamentet. 
Än mer intressant är dock att undersöka om orsakerna bakom väljarrörlighet skiljer sig åt mellan Öst och Väst. Om så är fallet kan det ge en indikation på om trenderna håller på att konvergera eller om det finns anledning att tro att de kommer att brytas. I tabell 4 undersöks de 50 valen i Västeuropa separat, i tre modeller. I den första blir ingen variabel signifikant och i modell 2 når endast korruption nätt och jämnt över den acceptabla signifikansnivån. Inte ens antalet effektiva parlamentariska partier kan förklara volatiliteten i Väst, än mindre tidigare volatilitetsnivåer. När vi byter ut variabeln antalet effektiva parlamentariska partier mot antalet effektiva partier som deltar i val i modell 3, blir denna dock signifikant samtidigt som korruptionsvariabeln stärks något. Däremot förblir tidigare volatilitet helt okorrelerad med den beroende variabeln. Den förklarade variansen ökar också dramatiskt från .14 i modell 2 till .41 i modell 3.

Tabell 4. Förklarad väljarrörlighet i Västeuropa 2008-2019.

\begin{tabular}{lccc}
\hline & $\begin{array}{c}\text { Modell 1 } \\
\text { Beta } \\
\text { (standardfel) }\end{array}$ & $\begin{array}{c}\text { Modell 2 } \\
\text { Beta } \\
\text { (standardfel) }\end{array}$ & $\begin{array}{c}\frac{\text { Modell 3 }}{\text { Beta }} \\
\text { (standardfel) }\end{array}$ \\
\hline $\begin{array}{l}\text { Korruption } \\
\text { (laggad) }\end{array}$ & $-1,320$ & $-1,989^{\star}$ & $-2,087^{\star \star}$ \\
ENPP & $(1,049)$ & $(1,128)$ & $(0,993)$ \\
ENEP & & 1,256 & \\
& & $(0,845)$ & $2,072^{\star \star \star}$ \\
Arbetslöshet & & & $(0,672)$ \\
(laggad) & 0,67 & 0,77 & 0,056 \\
Årlig tillväxt & $(0,291)$ & $(0,287)$ & $(0,266)$ \\
(laggad) & $-0,131$ & $-0,076$ & $-0,016$ \\
Föregående volatilitet & $(0,295)$ & $(0,294)$ & $(0,273)$ \\
(genomsnitt två val) & 0,104 & 0,037 & $-0,011$ \\
Konstant & $(0,226)$ & $(0,228)$ & $(0,210)$ \\
& $23,721^{\star \star}$ & $23,673^{\star \star}$ & $19,519^{\star \star}$ \\
$\mathrm{R}^{2}$ & $(9,847)$ & $(9,718)$ & $(9,131)$ \\
$\mathrm{N}$ & 0,10 & 0,14 & 0,41 \\
\hline
\end{tabular}

Kommentar: ${ }^{\star} \mathrm{p}<10 \%,{ }^{\star \star} \mathrm{p}<5 \%,{ }^{\star \star \star} \mathrm{p}<1 \%$. ENPP avser antalet effektiva partier i parlamentet och ENEP avser antalet effektiva partier som ställer upp i val.

Koefficienterna för Central- och Östeuropa skiljer sig markant från dem i Väst. I modell 1 är det endast korruption som är inte är signifikant, medan den nyintroducerade variabeln, den genomsnittliga volatiliteten för de två föregående valen, får stöd och med en tämligen stark effekt. I modell 2 när ENPP introduceras försvagas denna faktor något, men är fortfarande signifikant på den lägsta nivån. När vi 


\section{ANDREAS BÅGENHOLM}

däremot byter ENPP mot ENEP i modell 3 försvinner signifikansen även för tidigare volatilitet, medan de båda ekonomiska variablerna förblir signifikanta liksom ENEP. Som diskuterats i metodavsnittet kan det dock diskuteras huruvida antalet effektiva partier verkligen är en oberoende variabel i sammanhanget. Man skulle lika gärna kunna se det som en alternativ beroende variabel och det blir därmed en tolkningsfråga om man ska betrakta tidigare volatilitet som en relevant förklaringsfaktor eller ej. Hur man än förhåller sig till resultaten nedan anser jag att detta är en faktor värd att ta $\mathrm{i}$ beaktande $\mathrm{i}$ framtida studier på området.

Tabell 5. Förklarad väljarrörlighet i Central- och Östeuropa 2008-2019.

\begin{tabular}{lccc}
\hline & $\begin{array}{c}\text { Modell 1 } \\
\text { Beta } \\
\text { (standardfel) }\end{array}$ & $\begin{array}{c}\text { Modell 2 } \\
\text { Beta } \\
\text { (standardfel) }\end{array}$ & $\begin{array}{c}\frac{\text { Modell 3 }}{\text { Beta }} \\
\text { (standardfel) }\end{array}$ \\
\hline Korruption & $-1,098$ & 0,147 & 0,026 \\
(laggad) & $(1,939)$ & $(2,008)$ & $(1,934)$ \\
ENPP & & 2,479 & \\
ENEP & & $(1,697)$ & $2,318^{\star}$ \\
& & & $(1,214)$ \\
Arbetslöshet & & & $-1,081^{\star \star}$ \\
(laggad) & $-1,183^{\star \star}$ & $-1,150^{\star \star}$ & $(0,498)$ \\
Årlig tillväxt & $(0,519)$ & $(0,509)$ & $-0,935^{\star \star}$ \\
(laggad) & $-0,916^{\star}$ & $-0,922^{\star \star}$ & $(0,430)$ \\
Föregående volatilitet & $(0,451)$ & $(0,442)$ & 0,319 \\
(genomsnitt två val) & $0,546^{\star \star}$ & $0,402^{\star}$ & $(0,224)$ \\
Konstant & $(0,199)$ & $(0,219)$ & 17,317 \\
& 18,973 & 17,021 & $(12,258)$ \\
$\mathrm{R}^{2}$ & $(12,812)$ & $(12,622)$ & 0,37 \\
$\mathrm{~N}$ & 0,27 & 0,33 & 32 \\
\hline
\end{tabular}

Kommentar: ${ }^{\star} \mathrm{p}<10 \%,{ }^{\star \star} \mathrm{p}<5 \%$. ENPP avser antalet effektiva partier i parlamentet och ENEP avser antalet effektiva partier som ställer upp i val.

\section{Diskussion}

Analysen ovan visar att det fortfarande finns en betydande skillnad mellan Västeuropa å ena sidan och Central- och Östeuropa å den andra vad gäller graden av stabilitet i partisystemen. Både när vi mäter den totala väljarrörligheten och när vi smalnar av den till att bara gälla nya och utbrytarpartiers framgångar är effekten av regiontillhörighet signifikant under kontroll för ett antal faktorer som på goda grunder skulle kunna tänkas påverka detta fenomen. Detta i motsats till tidigare studier som inte hittat någon effekt under perioden 2010-2016 (Emanuele et al., 2018). Däremot visar undersökningen i likhet med den tidigare studien att det finns 
en konvergerande trend sett till de senaste 12 åren. Trenden är klart tydligare vad gäller stöd för nya och utbrytarpartier än vad gäller väljarrörlighet och denna trend påvisar också mindre inomregionala skillnader i Öst över tid och det motsatta i Väst. Om trenden fortsätter är det bara en tidsfråga innan regiontillhörighet upphör att vara signifikant särskiljande. Möjligen kommer den ökande variationen i Väst att ge upphov till nya geografiska mönster.

För att kunna bedöma sannolikheten för att dessa trender håller i sig måste vi dock ta de faktorer som ligger bakom väljarrörligheten i respektive region i beaktande. Som framgår i tabell 4 och 5 skiljer sig förklaringarna åt. En rimlig hypotes vad gäller partisystemsstabilitet generellt är att den orsakas av ett starkt folkligt missnöje gentemot ländernas regeringar och en mer generell misstro gentemot de politiska institutionerna, vilket i Central- och Östeuropas fall, men även i vissa länder i Sydeuropa, rimligen har sin grund i utbredd korruption och fortsatt ekonomisk eftersatthet. Alla tillgängliga mätningar visar att misstroendet är betydligt mer utbrett i Central- och Östeuropa, till exempel vad gäller hur väl man uppfattar att demokratin fungerar och förtroendet för politiska institutioner samt att korruptionsnivåerna generellt sett är högre och levnadsstandarden lägre än den i Väst. Att detta får konsekvenser för medborgares röstbeteende är knappast förvånande. Vi kan till exempel se att valdeltagandet är väsentligt lägre i Öst än i Väst, och detta brukar normalt ses som ett tecken på att medborgarna hyser lågt förtroende och/eller att de inte har tilltro till att politikerna kan göra någon skillnad för dem.

Frågan är dock i vilken utsträckning korruption och ekonomiska faktorer kan förklara skillnaderna mellan Öst och Väst. Sett till hela regionen förefaller korruption snarare än de ekonomiska faktorerna vara den mest relevanta "missnöjesvariabeln", vilket också i så fall skulle förklara det starka stöd som nya partier som går till val på korruptionsbekämpning, så kallade antikorruptionspartier, haft i framförallt Central- och Östeuropa, men även i flera fall i Väst.

Om vi däremot analyserar de båda regionerna separat framkommer ett delvis annat mönster. Variationen i Central- och Östeuropa drivs inte av graden av korruption utan snarare av de ekonomiska faktorerna, medan det omvända gäller i Västeuropa. I bägge fallen spelar antalet relevanta partier en viktig roll, men som tidigare påpekats kan det diskuteras i vilken utsträckning dessa två variabler verkligen är oberoende, eller i vilken utsträckning de är en variant på den beroende variabeln. Ju större missnöjet är, desto större sannolikhet är det att fler partier deltar i val och får substantiellt stöd från medborgarna, vilket gör att variabeln ligger farligt nära volatilitet. Att inkludera dessa variabler innebär därför ett väldigt tufft test för övriga faktorer.

Den kanske mest intressanta skillnaden mellan Öst och Väst är enligt mitt förmenande dock en annan, nämligen den som handlar om hur tidigare volatilitetsnivåer påverkar kommande. Som framgått av analysen spelar denna faktor ingen som helst roll i Västeuropa, medan den har stor betydelse i Öst. Signifikansen av denna faktor kvarstår i alla specifikationer utom den där antalet partier som ställer upp i 
val inkluderas. Det är därmed rimligt att hävda att en viktig drivkraft i den fortsatta partisystemsturbulensen i Öst är inte så mycket starkt folkligt missnöje, utan snarare en öppenhet från såväl väljare som potentiella politiska entreprenörer för nya alternativ i politiken.

Väljarstabilitet kan sägas ha två komponenter, en utbudssida och en efterfrågesida. För att rörligheten ska bibehållas krävs att det finns ett utbud av nya partier att rösta på såväl som en efterfrågan hos väljarna. Saknas det utbud av nya partier, finns det per definition bara etablerade partier att rösta på och saknas efterfrågan kommer nya partier inte att vinna några framgångar. Utbud och efterfrågan är emellertid inte två icke-kommunicerande kärl, utan det finns tvärtom en stark interaktion dem emellan. Om det finns ett folkligt missnöje ökar chansen att politiska entreprenörer kommer att försöka pröva lyckan och starta nya partier och ju oftare sådana projekt lyckas, desto mer kommer detta att uppmuntra efterföljare. Ur ett väljarperspektiv minskar i ett sådant läge också riskerna med att satsa på ett nytt parti, eftersom man vet att sannolikheten för att det faktiskt har en god chans att komma in i parlamentet är stor. När ett sådant mönster upprepats ett antal gånger, kommer med stor sannolikhet också andelen etablerade partier att vara avsevärt mindre. Därmed skapas ett slags spiral som kan sägas reproducera instabilitet i val efter val: väljarna vet att en sådan röst inte är bortkastad och politiska entreprenörer vet att det finns "riskvilliga" väljare. Detta till skillnad från situationen i partipolitiskt stabila länder där logiken blir den omvända: eftersom nästan inga nya partier lyckas ta sig in i parlamenten kommer få vara villiga att starta nya partier och de som ändå ställer upp kommer att ha svårt att attrahera väljare eftersom dessa betraktar ett stöd för det nya partiet som en potentiellt bortkastad röst. Alltså, stabilitet föder fortsatt stabilitet och vice versa.

Det finns mycket i den postkommunistiska utvecklingen som stöder tesen om en "spårberoende» logik, det vill säga när ett land väl hamnat i en situation med hög partipolitisk turbulens är det väldigt svårt att ta sig ur den, även om de faktorer som en gång orsakade instabiliteten har försvunnit eller försvagats. Instabiliteten lever så att säga sitt eget liv.

Som nämnts ovan finns det dock också tecken på en viss stabilisering av partisystemen i Öst- och Centraleuropa samtidigt som en ökad destabilisering äger rum i Väst. Frågan är hur dessa trender ska tolkas. En titt i backspegeln avslöjar att det inte funnits några tendenser till stabilisering fram till 2012 (Bågenholm \& Johansson Heinö, 2013) och man kan därmed fråga sig om den trend som kan skönjas under de senaste 12 åren är en tillfällig förändring eller ett långvarigt och stabilt mönster. Drar man ut trendlinjerna kommer de oundvikligen att mötas och därefter korsas, men är detta verkligen en trolig utveckling? Som diskuterats ovan är skillnaderna fortfarande betydande och ett stort antal val i Öst fortsätter att leverera hög volatilitet och nya framgångar för nya partier. I Västeuropa däremot förefaller den ökade väljarrörligheten huvudsakligen komma från ett fåtal länder och i ett fåtal val, medan flertalet val i regionen fortsatt går i stabilitetens tecken. Om en konvergens sker kommer det med all sannolikhet inte att vara rimligt att prata om Västeuropa som 
helhet, utan snarare kommer det att bli än mer relevant att göra en åtskillnad inom regionen. Som också påpekats är trendlinjerna känsliga för enstaka val, vilket gör att sluttningen snabbt kan förändras. Det främsta argumentet mot att en konvergens är förestående är dock de olika förklaringar som väljarrörligheten har i Väst resp. Öst. Om man ska tro analysen ovan så är den ökande turbulensen i väst huvudsakligen en funktion av korruption, vilket är ett svårlöst problem, men dock något som går att reducera. Det är inte orimligt att tro att partisystemsstabiliteten kommer att öka i regionen som helhet, men det finns också skäl att anta att det gångna decenniets ökande turbulens berodde på finans- och flyktingkriser och när väl dammet från dessa lagt sig, kommer också partipolitiken att stabiliseras, fast möjligen på en högre volatilitetsnivå än tidigare.

I Central- och Östeuropa däremot drivs den partipolitiska turbulensen i stor utsträckning av sig själv, det vill säga oberoende av missnöjesfaktorer i ett slags stigberoende som är mycket svårt att bryta sig loss från, vilket diskuterats ovan. Det finns därmed få skäl att tro att partipolitiken helt plötsligt ska hitta en stabil form som sedan reproduceras val efter val, utan det är snarast den omvända logiken som man kan förvänta sig. Det innebär i så fall att det kommer att dröja innan "de två», det vill säga Öst och Väst, kommer att mötas.

Det tycks finnas en uppfattning bland forskare att partipolitisk turbulens, med hög väljarrörlighet och ideliga framgångar för nya partier, är något entydigt negativt som hindrar demokratin från att konsolideras. Dessa ståndpunkter brukar dock framföras utan några klara empiriska belägg för att så skulle vara fallet och sådana studier saknas. Det finns goda argument för såväl en negativ som en positiv tolkning, men i avvaktan på att effekterna i olika avseenden av en dylik turbulens undersökts systematiskt, då vi kan avgöra om det är "bättre» eller "sämre» med denna ordning, får vi nöja oss med att konstatera att skillnaderna består.

\section{Om artikeln}

Jag vill tacka Rune Holmgaard Andersen samt två anonyma bedömare för synnerligen värdefulla kommentarer, vilka har förbättrat textens kvalitet avsevärt.

\section{Referenser}

Bartolini, S. \& Mair, P. (1990). Identity, competition and electoral availability. Cambridge: Cambridge University Press.

Bielasiak, J. (2002). The institutionalization of electoral and party systems in postcommunist states. Comparative Politics, 34, 189-210.

Birch, S. (2001). Electoral systems and party system stability in post-communist Europe. I 97th Annual meeting of the American Political Science Association, San Francisco, 30th August-2nd September.

Bågenholm, A. \& Johansson Heinö, A. (2013). Why are the post-communist party systems not stabilizing. ECPR foint Sessions, Mainz, 12-16.

Casal Bértoa, F., Deegan-Krause, K. \& Haughton, T. (2017). The volatility of volatility: Measuring change in party vote shares. Electoral Studies, 50, 142-156.

Chiaramonte, A. \& Emanuele, V. (2017). Party system volatility, regeneration and de-institutionalization in Western Europe (1945-2015). Party Politics, 23(4), 376-388. 


\section{ANDREAS BÅGENHOLM}

Elster, J., Offe, C. \& Preuss, U. (1998) Institutional design in post-communist societies: Rebuilding the ship at sea. New York: Cambridge University Press.

Emanuele, V., Chiaramonte, A. \& Soare, S. (2018). Does the Iron Curtain still exist? The convergence in electoral volatility between Eastern and Western Europe. Government and Opposition, 1-19.

Engler, S. (2016). Corruption and electoral support for new political parties in central and eastern Europe. West European Politics, 39(2), 278-304.

Epperly, B. (2011). Institutions and legacies: Electoral volatility in the postcommunist world. Comparative Political Studies, 44(7), 829-853.

Evans, G. (2006). The social bases of political divisions in post-communist Eastern Europe. Annual Review of Sociology, 32, 245-270.

Gallagher, M. (2019). Election indices. Trinity College, Dublin. Hämtat 2 oktober 2019 från www.tcd.ie/ Political_Science/people/michael_gallagher/ElSystems/Docts/ElectionIndices.pdf

Haughton, T. \& Deegan-Krause, K. (2015). Hurricane season: Systems of instability in central and east European party politics. East European Politics and Societies, 29(1), 61-80.

Innes, A. (2002). Party competition in postcommunist Europe: The great electoral lottery. Comparative Politics, 35(1), 85-104.

Kitschelt, H., Mansfeldova, Z., Markowski, R. \& Tóka, G. (1999). Post-communist party systems: Competition, representation, and inter-party cooperation. New York: Cambridge University Press.

Kopecky, P. (1995). Developing party organizations in East-Central Europe: What type of party is likely to Emerge? Party Politics, 1(4), 515-534.

Lane, J.-E. \& Ersson, S. (2007). Party system instability in Europe: Persistent differences in volatility between West and East? Democratization, 14(1), 92-110.

Lewis, P. G. (2006). Party systems in post-communist Central Europe: Patterns of stability and consolidation. Democratization, 13(4), 562-583.

Lipset, S. M. \& Rokkan, S. (Red.) (1967). Party systems and voter alignments: Cross-national perspectives (s. 1-67). New York: Free Press.

Lupu, N. \& Stokes, S. (2010). Democracy, interrupted: Regime change and partisanship in twentieth-century Argentina. Electoral Studies, 29(1), 91-104.

Mainwaring, S. \& Zoco, E. (2007). Political sequence and the stabilization of interparty competition: Electoral volatility in old and new democracies. Party Politics, 13(2), 155-178.

Mair, P. (1997). Party system change. Approaches and interpretations. Oxford: Clarendon Press.

McAllister, I. \& White, S. (2007). Political parties and democratic consolidation in post-communist societies. Party Politics, 13(2), 197-216.

Nordsiek, W. (2019). Parties and elections in Europe. Hämtat 2 oktober 2019 från www.parties-and-elections.eu

Pedersen, M. (1979). The dynamics of European party systems: Changing patterns of electoral volatility. European fournal of Political Research, 7(1), 1-26.

Powell, E. N. \& Tucker, J. A. (2014). Revisiting electoral volatility in post-communist countries: New data, new results and new approaches. British fournal of Political Science, 44(1), 123-147.

Rose, R. \& Munro, N. (2009). Parties and elections in new European democracies. Essex: ECPR Press.

Sikk, A. (2005). How unstable? Volatility and the genuinely new parties in Eastern Europe. European fournal of Political Research, 44(3), 391-412.

Tavits, M. (2005). The development of stable party support: Electoral dynamics in post-communist Europe. American fournal of Political Science, 49(2), 283-298.

Transparency International. (2019). Corruption perception index. Hämtat 2 oktober 2019 från https://www. transparency.org/research/cpi/overview

van Biezen, I. (2003). Political parties in new democracies: Party organization in Southern and East-Central Europe. Basingstoke \& New York: Palgrave.

Världsbanken. (2019). Hämtat 2 oktober 2019 från https://data.worldbank.org/indicator/ 